\title{
MINANGKABAU'S ADAT LAW REFLECTED IN ABDULKARIM KHIRATULLAH'S NOVEL MENCARI CINTA YANG HILANG
}

\author{
PUTRI ZAKIA \\ Akademi Keperawatan Ibnu Sina Kota Sabang \\ djaurmeutuah1985@gmail.com
}

\begin{abstract}
Minangkabau's Adat law has developed for centuries. In its development, Minangkabau's Adat law has given significant contributions to the dynamics and the continuity of Minangkabau's society. Minangkabau's society is matrilineal; it is not patriarchal in which the chief of a clan is always a man. In matrilineal, the women of the clan will be the chief and they can sack men if they do not do a good job. This paper studies first, what the types of Minangkabau's Adat laws are reflected in the novel; second, how the implementations of Minangkabau's Adat laws are in the novel. This study focuses on the analysis of Minangkabau's Adat law reflected in Abdulkarim Khiratullah's novel Mencari Cinta yang Hilang. As the research design is very crucial to conducting a research, this study applied descriptive qualitative research as its research design. It is important to carry out this research because it has fascinated many researchers due to the co-existence of contradictory elements with Islamic regulation like matrilineal family structure, marriage system and inheritance regulations.
\end{abstract}

Keyword: Minangkabau, Adat law, matrilineal.

\begin{abstract}
Abstrak
Hukum Adat Minangkabau telah berkembang selama berabad-abad. Dalam perkembangannya, hukum Adat Minangkabau telah memberikan kontribusi yang signifikan terhadap dinamika dan kelangsungan hidup masyarakat Minangkabau. Masyarakat Minangkabau adalah matrilineal; bukan patriarki di mana kepala klan selalu laki-laki. Dalam matrilineal, perempuan dari klan akan menjadi kepala dan mereka dapat memecat laki-laki jika mereka tidak melakukan pekerjaan dengan baik. Tulisan ini pertama mengkaji, apa saja jenis-jenis hukum Adat Minangkabau yang tercermin dalam novel tersebut; kedua, bagaimana implementasi hukumhukum Adat Minangkabau dalam novel tersebut. Penelitian ini berfokus pada analisis hukum Adat Minangkabau yang tercermin dalam novel Mencari Cinta yang Hilang karya Abdulkarim Khiratullah. Karena desain penelitian sangat penting dalam melakukan suatu penelitian, maka penelitian ini menggunakan penelitian kualitatif deskriptif sebagai desain penelitiannya. Penelitian ini penting
\end{abstract}


untuk dilakukan karena menarik banyak peneliti karena adanya koeksistensi unsur-unsur yang bertentangan dengan peraturan Islam seperti struktur keluarga matrilineal, sistem perkawinan dan peraturan waris.

Kata Kunci : Minangkabau, Hukum Adat, Matrialineal

\section{Introduction}

The State of Indonesia is a country which consists of various islands which have different languages, customs, religions and cultures from one another. With the diversity of customs, religions and cultures, Indonesian society is a pluralistic society which has the same meaning as the term plural or pluralistic society. Adat is an expression of culture, norm, and law and it is a system which has a certain non-neglected regulation. Adat can replace the customary law and can organize public purposes. Its development can be tailored to the circumstances of society at that time.(Arliman, 2018)

One of the provinces in Indonesia which run the Adat law is West Sumatra province. West Sumatra is the homeland of Minangkabau. Minangkabau is the ethnic in Indonesia which is known for the strength of their Adat or Adat law. Minangkabau's Adat law has developed for centuries. In its development, Minangkabau's Adat law has given significant contributions to the dynamics and the continuity of Minangkabau's society. Minangkabau's Adat law develops in an Adat village called Kenagarian. It forms the largest matrilineal society. Minangkabau's society is matrilineal; it is not patriarchal in which the chief of a clan is always a man. In matrilineal, the women of the clan will be the chief and they can sack men if they do not do a good job.

The life in Minagkabau was defined by a matrilineal way of life. This means there are certain kinship groups which follow the female descent of a mother. The woman's brothers are responsible for the children of her sisters rather than her husband (Stark, 2013: 2)

It is important to carry out this research because it has fascinated many researchers due to the co-existence of contradictory elements with Islamic regulation like matrilineal family structure, marriage system and inheritance regulations. To analyze the problem, the researcher will focus on the types of Minangkabau's Adat law and the implementations of Minangkabau's Adat law reflected in Abdulkarim Khiratullah's novel Mencari Cinta yang Hilang.

\section{Research Design}

Research design is any form of systematic and arranged investigation to organize facts or gather data, and is often related to a problem that has to be solved. Research is the study of materials, sources, and data in order to get conclusions. Any research is at the center of the process of learning about the world, and it is important that people understand how good research is organized. People depend on the accumulated knowledge and experience of the civilization. Research is the process the civilization uses to construct further on the store of knowledge. 
As the research design is very crucial to conducting a research, this study applied descriptive qualitative research as its research design. Moleong states that qualitative research is a research that results analysis procedure, not statistical analysis (Moleong, 2007). This method constitutes observation, interview, and document analysis. Furthermore, he added that the qualitative research as a research procedure that results descriptive data in written words. According to Bogdan and Biklen as stated by Moleong qualitative research has some characteristics, they are: nature background, human as the instrument, qualitative method, inductive data analysis, and descriptive (Moleong, 2007). In other words, descriptive qualitative research is a research that results analysis procedure, not statistical analysis in which the result of the research constitues the data in written words.

The aim of qualitative research is to understand phenomena from what is undergone by subject descriptively using inductive words. Based on this, this study used qualitative method to analyze the data from the novel entitled Mencari Cinta Yang Hilang by Abdulkarim Khiratullah. The object of the study was Minangkabau's Adat law reflected in the novel and there are two dominant points directly concerned with the main object of the study, those are the types of Minangkabau's Adat laws and how the implementation of Minangkabau's Adat laws in the novel.

\section{The Terms of Adat Law}

According to Prof. Koesno as quoted by Ismail there are some terms which are used in Adat law, they are (Ismail, 2013: 11):

a. Adat law: this term has clear definition as the translation of Adat law.

b. Volksretch: this term is used as cityzenery law. In Indonesia, it is well known as cityzenery law. The cityzenery can be defined as those who are not ruler classes. The cityzenery law is the law which is derived from tradition and culture of Indonesian as an intact unity.

c. Customary law: this term is derived from English, in which the meaning does not agree with the understanding of Indonesia Adat law. If the term is used, it will be considered as if indonesia Adat law were fastened to English law.

d. Traditional law: this term does not agree with Indonesia Adat law, because Adat law is not indicated as traditional understanding. Traditional law is described as the law which cannot be changed all along time but Adat law is not (Ismail, 2013: 13).

Based on the explanation above, 'Adat law' is the most suitable term which can be used.

\section{The Minangkabau Society}

The name Minangkabau is thought to be a conjunction of two words, minang ("victorious") and kabau ("buffalo"). . The first mention of the name Minangkabau as Minangkabwa, is in the 1365 Majapahit court poem, the Desawarnana (or Nagarakrtagama) composed by MpuPrapanca. West Sumatra is the homeland of the Minangkabau. They form the largest matrilineal society in the world. According to recent statistics (2010) there are more than four million Minangkabau who reside in West Sumatra. But millions also live in other areas. 
The center of the Minangkabau culture is the highland of West Sumatra. This highland is 'traditionally' divided into three regions: Limapuluh Koto, Tanah Datar and Agam. All the areas outside (even the coastal areas of West Sumatra) are called rantau. The life in the core areas was defined by a matrilineal way of life. This means there are certain kinship groups which follow the female descent of a mother. In a simple way the lineage system in the highland of West Sumatra consists of clans which are divided into sub-clans and parts of sub-clans (Eric, 2019).

For most visitors the traditional houses are the extraordinary features of the province. Such a house is the home of a sub-clan. One mother with her daughters live there. In the back part of the house there are the rooms for the daughters. Whenever a daughter marries, the husband moves into the house of his wife. The matrilineal organization presides over inheritance and property. One sub-clan owns a certain number of lands. This is called haratopusako. On the other side there is the individual acquired property (harato pancaharian) (Suparman, 2005: 53).

The inheritance of communal land follows the matrilineal way, which means from grandparents to the brother of mother (mamak) and from mamak to his nephews. The other property (harato pancaharian) follows the usual way from the father to the son. And later on, the classification of those property changes will be classified as communal property (haratopusako). Later the son will pass this in his function as a mamak to his nephews. The Adat itself is more detailed as it differentiates between low ancestral property and high ancestral property. As soon as it is inherited, the self-earned property is turned into low ancestral property, and after several generations, it becomes high ancestral property.

\section{Adat law}

Generally speaking, Adat, a word derived from Arabic, is used throughout Indonesia to refer to the "customs" or "customary practices" of a group of people or as "a gloss for the allegedly immutable cultural forms that distinguish one collectively from another. At the local level, Adat has multiple meanings. It is contingent concept encompassing a wide range of customs and traditions unique to each of Indonesia's major ethnic groups. Depending on local variants, Adat may represent systems of governance based on oral traditions, antecedents and customary law, provide ceremonial protocol for marriages and funerals, houses and harvests, or determine patterns of land usage and entitlement. Adat and Adat law cannot be separated. They can be differentiated only as custom which has or does not have legal consequences. According to Van Vollenhoven as stated by Ismail that Adat law is the totality of the rules of conduct for natives and foreign Orientals that have, on the one hand, sanctions (therefore: law) and, on the other, are not codified (therefore: Adat) (Ismail, 2013: 16).

Adat law was first introduced by Prof. Snouck Hurgrounje in 1894 (Ismail, 2013: 21). Like the other law, Adat law is also one of the laws which develop in the society. Adat law is a guide and character implementation of daily activity practice in the society life which has a society group characteristic in a country. Its characteristic is traditional and unwritten which is based on their Adat. The explanation bellow will show the definition of Adat law according to some experts. 


\section{Adat law by Soekanto}

Adat law is a concrete of consciousness of the law, especially in the society with the simple social structure and culture. He added there is an inclination that Adat law comes from society and most of them live in Adat system. They obey, understand, follow, and commend the Adat law. There are three reasons why they obey the Adat law; (1) the obedience is caused by the functionaries command, (2) it is caused by the society desire, and (3) it is caused by their considering that Adat law is a justice.

In Minangkabau, the children of a marriage couple are inherited the clan from their mother, the heir is based on inheritance Adat law (without document), and they do not have the right of their father's wealth. So, based on Minangkabau's Adat law, the children are not the heirs of their parents' property wholly, but they are inherited their mother's. He added that Adat law is divided into:

a. Inheritance Adat law

Inheritance Adat law is one of the parts of civil law and kinship law. It is related to human life, all human beings will die and they will leave their property for their children. Inheritance law in Indonesia is influenced by the descent which is involved with the certain society. Inheritance law based on Minangkabau's Adat law is unique in which the children are not the heirs of their father's property, but they are inherited their mother's. Inheritance Adat law is distinguihed into: individual inheritance, collective inheritance, and majority inheritance. Minangkabau's inheritance Adat law follows the collective inheritance in which an heir inherits the property together with the other heirs. The property cannot be owned individually.

b. Marriage Adat law

Minangkabau forms the largest matrilineal society in the world. The life in Minagkabau is defined by a matrilineal way of life. This means there are certain kinship groups which follow the female descent of a mother. The woman's brother is responsible for her children rather than her husband. In Minangkabau, if the men or women want to get married, they are prohibited to marry the women or men who come from the same clans.

c. Delik Adat law

Delik Adat law constitutes violation of Adat law. It means an action which is done by someone or some people offends equilibrium of society. This violation must be replaced with a punishment or Adat ceremony.

d. Land Adat law

In the society of Adat law, land is the most important thing that they have. It constitutes a place for them, and it also gives them life. It is called tanah ulayat. They have a chace to benefit from the wealth of the land such as crops. However, the land cannot be owned individually.

e. Kinship Adat law. 
Kinship Adat law is an Adat law which organizes individual status based on the descent in the family such as children's status toward their parents and their relative.

\section{Adat Law by Ismail}

Adat law is one of the unities of behaviour existing in society life and there will be punishment for those who violate the Adat law. He added that Adat law is society behaviour which develops as the social order of society that must be obeyed with the awereness and responsibilities used as directive in the society life in which the functionaries of Adat law have the important role, and the material of the law is not codified. Adat and Adat law cannot be separated. They can be differentiated only as custom which has or does not have legal consequences. Adat law as the totality of the rules of conduct for natives and foreign Orientals that have, on the one hand, sanctions (therefore: law) and, on the other, are not codified (therefore: Adat).

According to Nasroen as stated by Ismail, Minangkabau Adat law can be distinguished in different levels, they are (Ismail, 2013: 18):

a. Adat nan sabana Adat (the true Adat). This Adat is like the root of the Minangkabau way of life. It is related to the religion. This means that the rule is what is allowed or forbidden according to the religion. But it also contains the matrilineal way of life.

b. Adat nan di Adatkan (the Adat which was applied to Adat). This part of the Adat takes as points of reference the words and sayings which were conveyed by the ancestors Dt. Perpatihnan Sabatang and Dt. Katumanggungan. Parts of this Adat are never changed. It could be considered to be a core element. But there is also a flexible element. It allows the acceptance of decisions which were passed through consensus.

c. Adat nan teradat (the Adat that becomes accidentally Adat) contains the lifestyle like for example the wearing of blue jeans.

d. Adat-istiAdat regulates the daily ceremonies like marriage, birth, and etc. These are different from village to village.

\section{Adat Law by Setiady}

Adat comes from human individuality that has intelegence to do what they want to do. The behavior that he does regularly then becomes an individual customary. When the behavior is imitated by someone, it will be his costumary. Gradually, this customary become Adat in the society. In short, it can be stated that Adat is a customary which is existing in the society. Then the society consider that Adat as the customary that should be done by every people, and there will be a saction for those who violate the Adat, and it is called Adat law. In other words, Adat law is Adat that is accepted and must be obeyed by people in a certain society. They who violate the Adat will be punished.

\section{Review of Related Study}

In this sub-chapter, the writer would like to review two researches done by Alexander Stark and Arizal Rias respectively. The first research was done by Alexander Stark in 2013. In his his research entitled The Matrilineal System of the Minangkabau and Its Persistence Throughout History: A Structural Perspective. In 
the research he stated that the matrilineal society of the Minangkabau has fascinated numerous researchers from around the world. The co-existence of a matrilineal family structure and system of inheritance on one side and an Islamic way of life on the other side has intrigued these researchers. However most of the researches have been descriptive or focused on a special element of the Minangkabau way of life. He used Taufik Abdullah and Frederick Errington's research, who tried to offer theoretical approaches about matrilineal life in Minangkabau, as his theoritical framework in doing his research, and his research will examine these approaches. This study had looked at the Minangkabau society and tried to answer why matrilineal structures could survive throughout time. The answer was that there were core elements (in the sense of Errington) which allow an opposition (in the sense of Abdullah) and so it can reach a new stage without touching this core.

The second was from Arizal Rias' study in 2014 entitled Customary Crime Settlement Based on the Adat Law of Minangkabau: A Criminological Study. In this research, he showed that delik adat is all acts or incidents which are opposite to decision, familiarity, order, securityand justice, law knowledge of society in question, social response arise to restore social balance. Resolution against the aforementioned has been carry out based on customary law of Minangkabau through KAN works with community figures and alim ulama, intellectuals. Their decision which have been made to members of the society who violate the law are acceptable and there are no cases brought to the the courts. By application customary sanction against delik adat, it becomes a warning for the people that are important to obey and uphold the customary law of Minangkabau. Adat crime according to Adat law of Minangkabau happens when an act violates the Act of 20 (Undang-Undang Nan 20). This act regulates of conduct, behaviours and acts of people in its community. According to Adat Nagari (KAN) which consists of Adat functionaries, the existence of KAN has been upheld by Perda Sumatera Barat No. 131983 and the Circulation letter 1985 of higher court of Sumetera Barat. Indonesian Supreme Court has also upheld the existence of Adat law. In its decision No. 1644 K/Pid/1998, May 15, 1991 Supreme Court turned down the charge of prosecutor with the argument that the accused has been tried and punished according to Adat Law. However, there should be some improvements in procedure, administration and skill of KAN so that it may follow the development in society, science and technology.

From the two examples above it shows that the first research by Alexander Stark is about why matrilineal structures could survive throughout time. The answer was that there were core elements (in the sense of Errington) which allow an opposition (in the sense of Abdullah) and so it can reach a new stage without touching this core. However, in order to understand the reason how the matrilineal Adat could persist throughout the historical events, it was necessary to look at the concept of the Adat in more detail. It was stressed that there is a core element which will not change and there are elements which do adjust. It was also mentioned that the dualistic concept can be seen in a broader frame which gives opportunities for further research. Whereas, the second research by Arizal Rias is about resolution against the aforementioned has been carry out based on customary law of Minangkabau through KAN works with community figures and 
alim ulama, intellectuals. Their decision which have been made to members of the society who violate the law are acceptable and there are no cases brought to the the courts. By application customary sanction against delik adat, it becomes a warning for the people that are important to obey and uphold the customary law of Minangkabau (Nurdin \& Tegnan, 2019)

My research is about is about the types and the implementations of Minangkabau's Adat law in term of inheritace Adat law, marriage Adat law, delik Adat law, land Adat law, and kinship Adat law reflected in the novel. The findings of this study show that the types and the implementation of Adat law in Minangkabau are somewhat different from those in other places in Indonesia.

\section{Analysis and Finding}

\section{The types of Minangkabau's Adat Law}

There are some types of Adat law in Minangkabau, such as; inheritance adat law, marriage Adat law, delik Adat law, land Adat law, and kindship Adat law.For these matters, the analysis focuses on the types of Minangkabau's Adat law in Abdulkarim Khiratullah's novel Mencari Cinta Yang Hilang. The analysis of the types of Minangkabau's Adat law is based on the theory of Soekanto (1983) which was already presented in the paragraph above. The types of Minangkabau's Adat law analysed are: inheritance adat law, marriage Adat law, delik Adat law, and kindship Adat law.

\section{a. Inheritance Adat law}

Inheritance Adat law is one of the parts of civil law and kinship law. It is related to human life. All human beings will die and they will leave their property for their children. The property is distinguished into low ancestral property and high ancestral property. The low ancestral property is the property which is obtained by the husband and the wife together. Whereas, the high ancestral property is the property which is inherited from one generation to the other generation. In Minangkabau, the low ancestral property is inherited by parents to their children. Whereas the high ancestral property will be inherited from mother to the daughter and so on.

The law of inheritance in Minangkabau is a part of customary laws arranged regularly under the laws of the mother. It is, according to Minangkabau adat law, calculated on the maternal lineage. How principles and legal determination of heirs in Minangkabau are discussed below.

\section{The high ancestral property will be inherited from mother to daughter}

Matrilineal system is not only a rule, but also a culture, and way of life. It is the most inner tendency of each of the Minangkabau's people. Until now, Minangkabau people inherit their property, such as high ancestral property which should be shared toward their daughter. They are more inclined to give it to her daughter. Then the daughter will give it to her daughter too and so on. According to Ismail, Minangkabau is one of ethnics in Indonesia that follows materilineal system, in which the inheritance will be given only to daughter and continued to the grand daughter and so on (Ismail, 2013).

In the novel it is seen that the high ancestral property is inherited from grand mother to mother and from mother to daughter. The men in the 
family have no right toward the high ancestral property beacuse it belongs to mother and will be inherited to her daughter.

\section{Minangkabau's inheritance Adat law follows the collective inheritance}

In Indonesia, there are three types of inheritance system, they are: individual inheritance system, collective inheritance system, and majority of legacy systems. In this case, Minangkabau ethnic follows the collective inheritance system in which the heirs receive their inheritance collectively (together) from their parents. According to this inheritance system, the heirs do not have the right toward the property individually, but they are allowed to use the property and enjoy the crop from it (Minangkabau: "ganggam bauntui"). Generally, the collective inheritance constitute the land (agriculture) or goods heritage, rice field, the longhouse controlled by Mamak who is the chief of the family and used by the nephew together. It means that the property cannot be owned individually because it belongs to all members of the family.

\section{Marriage Adat law}

there are 3 types of marriage system in marriage Adat law; they are: endogami marriage system, exogami marriage system, eleutherogami marriage system. Endogami marriage system is a marriage which happens among people who come from the same clan, like in Toraja, Sulawesi. Exogami marriage system is a marriage which happens among the people who come from the other clans, like in Minangkabau, Tapanuli, Gayo, Alas, and etc. Whereas, eleutherogami marriage system is a marriage which prohibits someone to marry people from the same descent (mother, daughter, grand daughter, and etc), like in Aceh, Bangka Belitung, Kalimantan, Minahasa, and so etc.

In this case, Minangkabau follows Exogami marriage system. Minangkabau forms the largest matrilineal society in the world. The life in Minagkabau is defined by a matrilineal way of life. It means that there are certain kinship groups which follow the female descent of a mother. Ismail states that in Minangkabau, a husband does not constitute the wife's family, but the children (Ismail, 2013). A husband does not have authority over their children. Thus, the children are under the authority of their mother. The followings are the description of the rules.

Based on Minangkabau's Adat law, the father is like a guest in his wife's house. The wife's brother has more important role on the children than the the children's father (Soekanto, 2010). Minangkabau also follows the rule where the kinship system is based on the female descent. In Minangkabau, a woman is entrusted property of the tribe for generations. Men cannot own the property arbitrarily, as happened in the patrilineal system. The men only manage his family ancestral property and cannot own it individually.

Minangkabau matrilineal system gives a proportional function to men and women. Men are as the managers and women are as the owners of the property. In education, a child is educated by the brother of his mother (Mamak) while his father serves for a living by using the property of the woman.

\section{Exogami Marriage System}


exogamy, also called out-marriage, custom enjoining marriage outside one's owngroup. Exogamy is usually defined through kinship rather than ethnicity, religion, or class. It is most common among groups that reckon descent through either the father (patrilineality) or the mother (matrilineality) alone. Such lineages may in turn be grouped into clans or moieties. These are most often the locus of exogamy; marrying a member of one's own clan or moiety typically constitutes a form of incest.

Human beings will not be able to develop well without a process. The process is called marriage. Through marriage, children will be born well and legaly. Through the good and legal descendants, a good family will be created and they will become good society. Setiady states that marriage can produce a good human being in a society. But marriage is not only a relationship process which only happens between two persons, but also between two parents, brothers and families (Setyadi, 2009: 221). In Minangkabau's marriage Adat law, a person is prohibited to marry someone from the same clan (exogami marriage system), because they are considered as siblings.

\section{Delik Adat law}

Delik Adat is the customary legal rules governing the actions of violation that causes disruption to the balance in people's lives (Ismail, 2013: 268). So, the balance of the community is not compromised. Delik Adat is an act which is contradictory to obedience, order and peace of society tangibly or intangibly done individually or in groups. Then, those who violate the law should be punished. According to Setiady, there are some actions considered as delik Adat. They are (Setyadi, 2009: 347):

1. The action which vioalates the norms of Adat law, such as in Minangkabau. Marrying people who come from the same clan is considred as a violation toward Adat law.

2. The actions considred offending the balance of society are: killing, stealing, pregnant without wedlock, and etc.

Owing to the above description, it is said that the action constitutes violation of Adat law is Delik Adat law. It means that the law for an action or actions done by someone or some people who offend the equilibrium of society are delik Adat law. This violation must be replaced with a punishment or Adat ceremony.

The violation of Adat law is an action which contradicts to the rule of Adat law which is considered offending the society life. If this happens. there will be punishments for those who violate the Adat law. In Abdulkarim Khiratulah's novel Mencari Cinta Yang Hilang, it shows that the protagonist (Fauzi) wants to marry the girl (Rahima) who comes from the same clans as him but it is prohibited by the adat because they are considered as sibling. If he does it he will be considered as a violator of Adat law. The violators of Adat law will be punished because of offending the tranquility of society life. So, the protagonist does not mary Rahima because he knows the consequence of violation Adat law.

\section{Land Adat law}

In our society, in the term of Adat law, land is the most important thing to have because it gives us life. In Minangkabau, a clan has the land 
which is belonged to all member of the clan which is called communal land or Tanah Ulayat. The members of the clan have the opportunity to gain some benefits from the land like harvesting the plants. but it cannot be owned individually.

Tanah Ulayat is a communal land which is considered as the highest right which cannot be inherited to other persons or cannot be owned individually. It means that, in Minangkabau, Tanah Ulayat should not be inherited to the children of a family because it belongs to all families in a clan. The members of the clan only have the right to wear and use it. In Abdulkarim Khiratulah's novel Mencari Cinta Yang Hilang, It shows that the protagonist (Fauzi) wants to continue his study to Middle East, but his mother does not have enough money, so all members of his family decided to sell the land.

\section{Kinship Adat law}

According to Setiady, Kinship Adat law is an Adat law which organizes individual status based on the descent in the family such as children's status toward their parents and their relative (Setyadi, 2009: 205). Generally, the children's status in a family will depend on the society where they live in. The status of children will base on the kinship system. There are three types of kinship system, they are: parental, patrilineal, and matrilineal. In the parental which is so called bilateral, the children's relation toward father are the same as their relation toward mother. So, marriage law, inheritance law, kinship law, and etc, toward both of the family are the same, for example in Java.

In another case, in patrilineal, the father has the most important role in a family. In this system, the children are inherited their father's clan (if there is a clan), for example in Batak. It is different from matrlineal society in which mother has the most important role in a family and their children are inherited the mother's clan, for example in Minangkabau.

The life in Minagkabau is defined by a matrilineal way of life. There are certain kinship groups which follow the female descent of a mother. Minangkabau society follows matrilineal kinship system. Matrilineal system is a system that regulates the life and order of a society which is bound in a tangle of kinship in the maternal line. The children inherits their mother clan and the father cannot. In Abdulkarim Khiratulah's novel Mencari Cinta Yang Hilang. it shows that the protagonist (Fauzi and Rahima) come from Minangkabau, so they inherit their mother clan.

Fauzi's father is Paliang and his mother is Caniago. Here, Fauzi inherits his mother clans, Caniago, and so does Rahima. In Minangkabau, a person cannot marry another who has the same clan. On the con trary, in Islamic law, the children are inherited their father. In Minangkabau, women have the more important role toward their children in a family than her husband. If her husband passes away, the women's brother will be responsible for his sister's family. Therefore, inheritance and heritage are handed down by the maternal line as well.

\section{The implementations of Minangkabau's Adat laws reflected in the novel.}

In this sub chapter, the writer described about the implementations of Minangkabau's Adat law in term of marriage Adat law, and delik Adat law. 


\section{Marriage Adat law}

A marriage not only unites a relationship between men and women, but also unites the relationship between the families. There are 3 types of marriage systems in adat law community, namely: endogamy marriage system, exogami marriage system, eleutherogami marriage systems. Endogamy marriage system is a marriage system that occurs between people who come from the same clan, as in Toraja, Sulawesi. Exogami marriage system is a marriage system that occurs between people who come from other clans, such as in Minangkabau, Tapanuli, Gayo, Alas, etc. Meanwhile, eleutherogami marriage system is a marriage system that prohibits a person to marry people of the same lineage (mother, daughter, grand daughter, and others), such as in Aceh, Bangka Belitung, Borneo, Minahasa, and others

Minangkabau as an ethnic which is well known for the strenght of Adat law, follows exogami marriage system in which it is prohibited to marry someone who comes from the same clan and it must be obeyed by every person in Minangkabau. This case is found in Abdulkarim Khiratullah's novel. The protagonist (Fauzi) falls in love with the girl (Rahima). Fauzi's clan is Caniago and so is Rahima. In Minangkabau, the people who comes from the same clans is considered as sibling, so they cannot get married.

the protagonist has done the engagement with Rahima, and he plans to hold the wedding two months later, but unluckily, after discussing with Ninik mamak, his planning is opposed by them. Ninik Mamak said that Fauzi and Rahima cannot get married because they have the same clan. They added that in Minangkabau, marrige between two people who have the same clan is prohibited. They will be considered as a violator if they do that.

\section{Delik Adat law}

Delik Adat law is an act that violates a sense of justice and adherence that offends the a balance of the society. In order to restore this situation, there was Adat reactions that have a purpose to recover disablement happened by doing a punishment for those who violate it. In other words, delik adat is all acts or incidents which are opposite to decision, familiarity, order, security and justice, and social respons. Resolution against the aforementioned has been carried out based on Minangkabau's Adat law through the Adat functionaries with community figures, and alim ulama. Their decision which have been made to members of the society who violate the law are acceptable. Applying the Adat sanction against delik adat becomes a warning for the people to obey and uphold the Minangkabau's Adat law.

The characteristics of delik Adat law is the crime act. It is different from the rules of Adat law. The crime act offends the balance, the harmony and the peacefulness of the society. Here, there is no difference between the criminal law and the civil law. The functionaries will issue the sanctions for those who violate the law. Abdulkarim Khiratullah's novel shows that delik Adat law is found here. The protagonist (Fauzi) intends to marry Rahima, but it is prohibited by Ninik Mamak, because it is considered as the violation of Adat law. They said there will be sanctions for those who violate Adat law.

In other word, we can say that delik Adat law is a violation done by someone who offends the equilibrium of society. There will be a punishment for those who 
violate this Adat law. Acording to Ismail, delik Adat law is norms that relate to a crime and violation in the society in which they offend the harmony and peacefulness in the life (Ismail, 2013: 268). Adat is a reflection of nation. The modernization cannot omit the customary developed in society. The development of Adat can adapt the situation of a nation. In addition, Adat in the society will became a source for Adat law.

\section{Conclusion}

Adat law is one of the law order. It is different from any other laws such as Rome law, Hindu law, etc. The development of Adat law in modernization era runs based on the evolution as a source of law in life. A unique Adat law is implemented in Minangkabau. Minangkabau is an ethnic who is well known for their strength of their Adat or Adat law. Minangkabau's Adat law develops in an Adat village called Kenagarian. They form the largest matrilineal society in the world. Minangkabau society is matrilineal.

Matrilineal system is a system that regulates the life and order of a society based on the maternal line. A boy or girl is a clan of their mother. The father cannot put their children into his clan as applicable in patrilineal system. In Minangkabau, wives have the important role toward their children in a family than husbands. If husbands pass away, wives' brother will be responsible for his sisters' family. The father is considered as the Samando which means he is like ashes on the stump, which will fly by the wind blast because he has no power at all. 


\section{Recommendation}

Based on the findings and limitation of this study, there are several areas that, the writer thinks, need further study. The first important areas which need further study are the other types of Minangkabau's Adat law and its implementation. Moreover, this study is based on library research, so that, the writer recommends that other researchers conduct the field research which somewhat equal to this topic.

During accomplishing the study, it was found that references on the subject matter were quite rare especially in the implementation of Minagkabau's Adat law. So, it is suggested that other researchers make further researches in order to provide some references and literature of the concerned topics which are badly needed by the other researchers. Finally, as Adat law is a reflection of a nation, it is recommended that the government take some actions to maintain the Adat of every region in Indonesia.

\section{References}

Arliman, L. (2018). Hukum Adat Di Indonesia Dalam Pandangan Para Ahli Dan Konsep Pemberlakuannya di Indonesia. Jurnal Selat, 5(2), 177-190. https: / / doi.org/10.31629/selat.v5i2.320

Eric, E. (2019). HUBUNGAN ANTARA HUKUM ISLAM DAN HUKUM ADAT DALAM PEMBAGIAN WARISAN DI DALAM MASYARAKAT MINANGKABAU. Jurnal Muara Ilmu Sosial, Humaniora, dan Seni, 3(1), 61. https://doi.org/10.24912/jmishumsen.v3i1.3532

Ismail, B. (2013). Asas-asas dan Perkembangan Hukum Adat. Banda Aceh: Boebon Jaya.

Moleong, L. J. (2007). Metodologi Penelitian Kualitatif (Edisi revi). Bandung: Remaja Rosdakarya.

Nurdin, Z., \& Tegnan, H. (2019). Legal Certainty in the Management of Agricultural Land Pawning in the Matrilineal Minangkabau Society, West Sumatra. Land, 8(8), 117. https://doi.org/10.3390/land8080117

Setyadi, T. (2009). Intisari Hukum Adat dalam Kajian Kepustakaan. Bandung: Alfabeta.

Soekanto, S. (2010). Hukum Adat Indonesia (Cetakan ke). Jakarta: Raja Grafindo Persada.

Stark, A. (2013). The Matrilineal System of The Minangkabau and Its Persistence Throughout History: A Structural Perspective (Southeast Asia: A Multidisciplinary Journal). Universiti Malaysia Kelantan, 13, 13.

Suparman, E. A. G. (2005). Hukum Waris Indonesia: Dalam Perspektif Islam, Adat, dan $B W$. Bandung: Refika Aditama. 